\title{
CNG PROPULSION SYSTEM FOR REDUCING NOISE OF EXISTING CITY BUSES
}

\author{
Saša Milojević* \\ University of Kragujevac, Faculty of Engineering, Kragujevac, Serbia \\ Dobrosav Gročić \\ Centre for engines and vehicles TehnoLab CMV d.o.o, Belgrade, Serbia \\ Dragić Dragojlović \\ Centre for engines and vehicles TehnoLab CMV d.0.o, Belgrade, Serbia
}

Noise pollution due to road traffic is a major global concern because of its negative impact on the quality of life in communities everywhere. In Republic of Serbia, traffic noise has become an increasingly noticeable and serious problem in large cities like Belgrade, Novi Sad, Niš, Kragujevacand Kraljevo. To resolving the current situation, in cities where exists the intensive noise pollution from diesel vehicles, as a special contribution to reducing noise in road traffic, we were studied the replacement of the existing city busses with new propulsion system on natural gas, resulting in less noise emission. The reduction of noise emission was confirmed during parallel tests of the buses with drive on diesel and natural gas. Intensive noise measurements were conducted according to the Regulation UN ECE 51R.

Key words: Road traffic noise, Natural gas buses, UN ECE 51R

\section{INTRODUCTION}

Noise pollution in urban areas has been globally recognized as a major detriment to the quality of life. The adverse effects of noise include various impacts on people's physical well-being and the disturbance of daily activities. Actions to control such effects have been an immediate concern for communities in countries of the developed world, as evidenced by a large body of regulations and noise policies. European Union (EU) indicates the noise emission as one of the ecological problems of modern society. According to the EU publication, about $40 \%$ of the population is exposed to road traffic noise at levels exceeding $55 \mathrm{~dB}(\mathrm{~A})$, that is upper limit for clearly residential territory. Through $20 \%$ of the population is exposed to the noise level in excess of 65 $\mathrm{dB}(\mathrm{A})$, that is upper limit for urban centres, commercial and administrative area with residences, zone along highway, main route and city roads, until above $30 \%$ of the European population is exposed to the noise level in excess of $55 \mathrm{~dB}(\mathrm{~A})$ nightly, that challenge the problems with dream [6]. The main causes of vibration and noise can be classified into four groups: the noise of structural and technological parameters, work processes and maintenance technologies. General- ly, relevant sources of environmental noise are: road and railway traffic, aircraft as well as, industries and ports. Vehicles involve all modes of noise generation: noise of air (ventilation, aerodynamics), hammering (pistons and transmission parts), friction (tyres), and pinching (wires, cables, pipes, metal plates). Noise is generated by two external sources: air and road surface contact, and by variety of internal origins such as mechanical vibration or fluid flow (intake and exhaust system). Practically, every part of a vehicle generates a sort of noise. The manufacturers of vehicles prefer on lowering noise at source, by using quieter propulsion system, on example. The above is followed by isolation of engine compartment with light materials that absorb noise. Currently in the city traffic we have the domination of buses with diesel propulsion system. Similar situation is with other means of transport. The diesel engine is an environmentally friendly engine because of its low consumption and the subsequent $\mathrm{CO} 2$ emissions reduction. In addition, novel technologies for combustion control and exhaust gas after-treatment continue to develop to comply with emissions legislation. However, diesel engines have faced serious acoustic problems. Due to the characteristic diesel combustion noise, the engine is considered to be the main 
source of noisein diesel-powered vehicles [03] Because of characteristics of working process in gas engines, their sound pressure is lower, compared to the appropriate diesel engine, which was confirmed during some researches [01]. The initial idea was that, by reduction of noise emission from engine, we can directly reduce and noise of vehicle. For that reason, we started researches during which it was realized and the reconstruction of city bus with diesel engine, for drive on compressed natural gas (CNG). The reconstruction was carried out, by installing the original engine for CNG (dedicated vehicle) [06]. After the reconstruction, was realized the appropriate measurement of noise of the bus, as well as other emission parameters. During the tests, we are measured the noise emission of the new bus variant (two domestic producers; the buses marked as CNG-1 and CNG-2) according to the Regulation UN ECE 51R [06,04].Based on the results, we are verified the reduction of noise in the case when used gas instead of the diesel engine.

\section{STANDARDS FOR LIMITING NOISE LEVELS OF MOTOR VEHICLES}

Emission of exterior vehicle noise is standardized with Regulation UN ECE 51R, current Amendment 03. Also relevant are Directive 70/157 EEC, as well as Directive 2002/49/EC. The above is relating on the protection from noise emission and represents the Regulation about the noise indicators, with defined limits and methods for evaluating the indicators of noise disturbance and adverse effects of noise in the environment. Both Directives, are introduced and legislated in the Republic of Serbia (Official carrier RS number 75/10), and have the objective at preventing and reducing harmful effects on the population, to establish, the database, which will be used to determine the strategy to reduce noise in the future $[03,04]$.

\section{RECONSTRUCTION OF THE DIESEL BUS TO DRIVE ON GAS FUEL}

The reconstruction of the city bus with diesel engine into dedicated vehicle(CNG-1 bus), in our case is started through the adaptation of engine compartment, where need to be mounted the original CNG engine, Figure 1. CNG engine must be supported by means of new appropriate dampers with corresponding damping characteristics. We used the classic methods of engineering, to determining characteristics of the mounts for engine, and joint solution for assembling. The position of engine and equipment for CNG is defined, by application of Finite Element Method (FEM/PAK). Specifically we are taken into account and the requirements to the lowering noise and vibrations. The engine compartment is completely encapsulated with materials for noise absorption $[06,05]$.

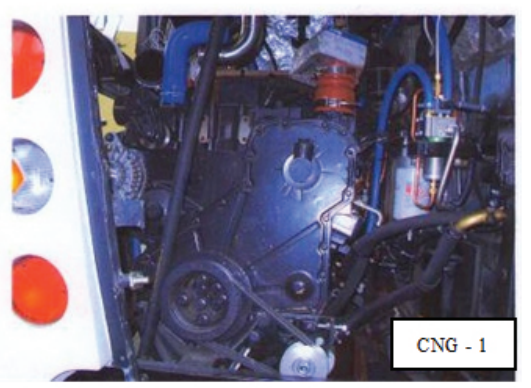

a) Rear engine support/ traverse (CNG-1)

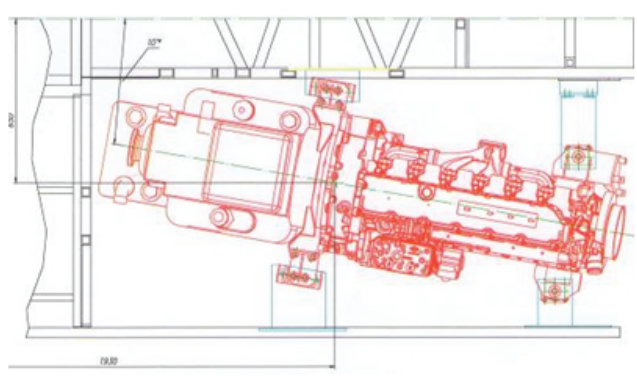

(b) Engine supporting cross four point (CNG-1)

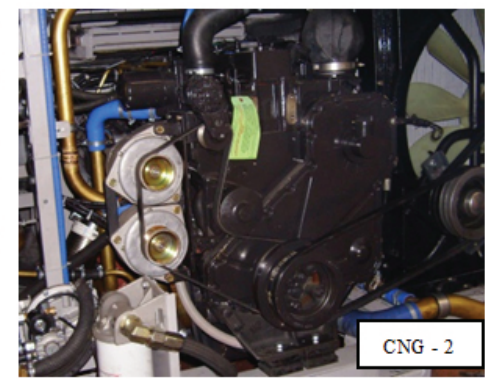

(c) Photography of engine compartment (CNG-2)

Figure 1: CNG engine position on the appropriate supports

\section{EXPERIMENTAL MEASUREMENTS}

In order to verify the reconstructions from the aspect of noise reduction, we are measured the noise emission, for both variants of buses (diesel and CNG), at polygon conditions. Methods of measurements are pursuant with the Regulation UN ECE 51R [04].The measurements have been made on reconstructed buses with similar propulsion system on CNG of two different producers.

\section{Measuring equipment}

Table 1 shows the specifications of measuring equipment for noise measurement according to the Regulation UN ECE 51R.Fig. 3.a. shows the photography of device for measuring noise.

\section{Technical characteristics of experimental buses}

The dimensions of reconstructed bus (CNG-1) with original CNG engine are shown in Figure 2. 
The comparative technical characteristics of buses type 203, in variant with both diesel and gas engine, as well as the CNG bus of second producer (CNG-2), are shown in Table $2[06,08]$.

Table 1: Specification of measuring equipment [06]

\begin{tabular}{|l|c|}
\hline \multicolumn{1}{|c|}{ Description / Name } & Specifications / Type \\
\hline Sound level meter type & Bruel\&Kjaer 2231 \\
\hline Microphone type & B\&K 4155 \\
\hline Filter set type & 1625 \\
\hline Sound level calibrator type & 4230 \\
\hline
\end{tabular}

\section{Noise emission measuring of buses at stationary conditions}

Measurements were carried out in accordance with the conditions defined in Regulation UN ECE 51R.We used a sound level meter with a microphone whose characteristics are shown in Table 1.The measuring device is placed at a distance of $(0.5 \mathrm{~m})$ from the exhaust pipe in the horizontal direction, Figure 3.b.

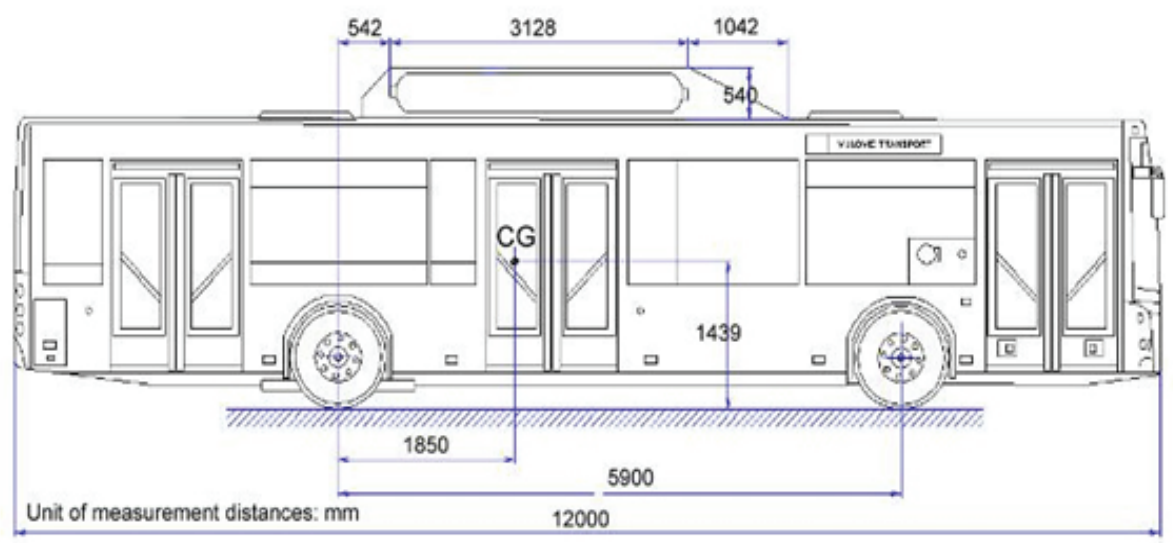

Figure 2: Dimensions of CNG bus, type 203

Table 2: Technical dates of buses tested comparatively

\begin{tabular}{|c|c|c|c|}
\hline $\begin{array}{l}\text { Technical dates of buses } \\
\text { and equipment }\end{array}$ & Diesel bus type 203 & $\begin{array}{c}\text { Gas bus type } \\
203 \text { CNG (CNG-1) }\end{array}$ & $\begin{array}{c}\text { Gas bus type } \\
\text { A537.4 CNG (CNG-2) }\end{array}$ \\
\hline $\begin{array}{l}\text { Engine maker } \\
\text { - type - configurationver- } \\
\text { sion } \\
\text { - no. of cylinders / Cycle } \\
\text { - } \text { engine capacity (cm3) } \\
\text { - maximum net power } \\
\text { - } \text { maximum net torque } \\
\text { - combustion system } \\
\text { - fuel } \\
\text { - type of catalytic action }\end{array}$ & $\begin{array}{c}\text { Mercedes-Benz } \\
\text { 2005/55-59C01 } \\
\text { OM 906 LA.V/3 } \\
6 \text { in-line / four stroke } \\
6374 \\
210 \text { kW @ 2200 rpm } \\
1120 \text { N-m@1200-1600rpm } \\
\text { Compression Ignition } \\
\text { Diesel } \\
\text { Selective Catalytic Reduc- } \\
\text { tion, SCR- System }\end{array}$ & $\begin{array}{c}\text { Cummins } \\
\text { D553005BX02 } \\
\text { CGe4 280 (TWC) } \\
6 \text { in-line / four stroke } \\
8268 \\
209 \text { kW @ } 2400 \text { rpm } \\
1148.8 \text { Nm @ 1400 rpm } \\
\text { Spark Ignition } \\
\text { Natural Gas } \\
\text { Oxidation - Ceramic in } \\
\text { Muffler casing }\end{array}$ & $\begin{array}{c}\text { Cummins } \\
\text { / } \\
\text { CGe4 } 280 \text { (TWC) } \\
6 \text { in-line / four stroke } \\
8268 \\
209 \mathrm{~kW} \mathrm{@} \mathrm{2400} \mathrm{rpm} \\
1148.8 \mathrm{Nm} @ 1400 \mathrm{rpm} \\
\text { Spark Ignition } \\
\text { Natural Gas } \\
\text { Oxidation - Ceramic in } \\
\text { Muffler casing }\end{array}$ \\
\hline $\begin{array}{l}\text { Gearbox maker } \\
\cdot \quad \text { type } \\
\cdot \text { gear change / number }\end{array}$ & $\begin{array}{c}\text { Voith } \\
\text { D 864.3E } \\
\text { Automatic / } 4 \text { speed }\end{array}$ & $\begin{array}{c}\text { Allison } \\
\text { T325 R } \\
\text { Automatic / } 6 \text { speed }\end{array}$ & $\begin{array}{c}\text { Allison } \\
\text { T325 R } \\
\text { Automatic / } 6 \text { speed }\end{array}$ \\
\hline
\end{tabular}

During measurement, the engine speed are set on the first idle value and then at $\left(18001 \cdot \mathrm{min}^{-1}\right)$ which represents $\left(3 \cdot 4^{-1}\right)$ speed of the same value at maximum engine power.It should be noted that the fan cooling system of diesel buses has one speed, while CNG buses have one more fan speed. All the time, the bus was stopped and the command the automatic transmission is in neutral. The values obtained by measuring of the noise emission in stationary conditions for two variant of bus type (diesel and CNG), are shown in Table 3. (CNG-1) bus meets the limits regu- 
lated with standard. Measured noise emission is much lower than the lower limit value of $80 \mathrm{~dB}(\mathrm{~A})$, which is defined by ECE regulations. Noise emission of (CNG-1) bus, on idle speed is lower by 7 (first speed) and $13 \mathrm{~dB}(\mathrm{~A})$ (second speed of fan in cooling system the engine), compared to the results obtained by testing diesel buses. During the operation on $\left(18001 \cdot \mathrm{min}^{-1}\right)$, the noise emission of (CNG-1) bus is lower for $22 \mathrm{~dB}(\mathrm{~A})$, Table 3. In case of (CNG-2) bus emission is bigger for 11 (first speed) and $9 \mathrm{~dB}(\mathrm{~A})$ (second speed of fan in cooling system the engine), compared to (CNG-1) bus, on idle speed. During operation on $\left(18001 \cdot \mathrm{min}^{-1}\right)$, the noise emission of (CNG2 ) bus is much bigger from regulated value. The measured values are rounded to the next bigger integer number, according to the standard demands, Table 3.

\section{Noise emission measuring of buses at driving conditions}

Measuring device is placed at a distance to the bus as presented on the Figure 3.c. The microphone is positioned at the height of $(1.2 \mathrm{~m})$ above the ground in the vertical direction and looking in the horizontal direction on the distance of $(7.5 \mathrm{~m})$ left and right from the reference line (CC'), which represents a direction of driving bus. On the polygon are marked two lines (AA') and (BB'), at a distance of $(10 \mathrm{~m})$ ahead and behind position of microphone.

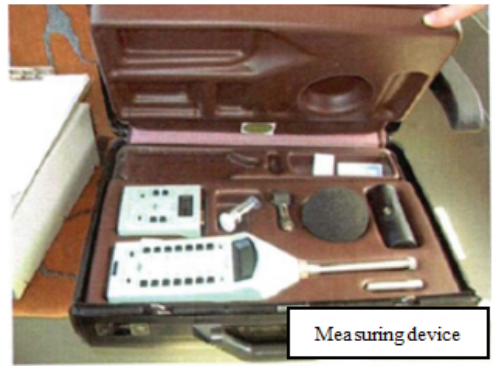

a) Photography of measuring device

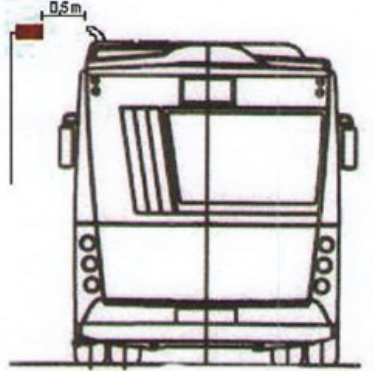

(b) Stationary conditions

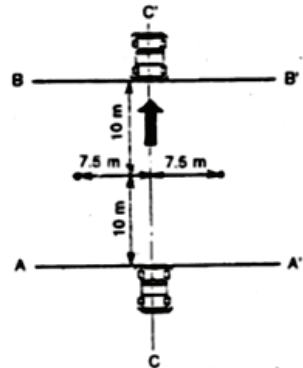

(c) Drive conditions

Figure 3: Photography and positions of the measuring device during testing

Table 3: Noise emission of conventional diesel and CNG buses at stationary conditions, $d B(A)$

\begin{tabular}{|c|c|c|c|c|}
\hline \multirow[b]{2}{*}{ Parameter } & \multirow[b]{2}{*}{ Powertrain } & \multirow[b]{2}{*}{ Measurement } & \multicolumn{2}{|c|}{ Engine speed } \\
\hline & & & Low idle & $\begin{array}{l}\text { High idle, } \\
18001 \cdot \mathrm{min}^{-1}\end{array}$ \\
\hline \multirow{9}{*}{ Average } & \multirow{3}{*}{ Diesel } & 1. & 76 & 97.5 \\
\hline & & 2. & 77 & 98 \\
\hline & & Results ... & 77 & 98 \\
\hline & \multirow{3}{*}{ CNG-1 } & 1. & $64 * / 70^{* *}$ & 76 \\
\hline & & 2. & $63.9^{*} / 69^{* *}$ & 75 \\
\hline & & Results... & $64^{*} / 70^{* *}$ & 76 \\
\hline & \multirow{3}{*}{ CNG-2 } & 1. & $74.5^{*} / 78.3^{* *}$ & 85.1 \\
\hline & & 2. & $74.9^{*} / 78.4^{* *}$ & 86.8 \\
\hline & & Results... & $75^{*} / 79^{* *}$ & 87 \\
\hline
\end{tabular}

Comment: *1st cooling fan speed, ${ }^{* *} 2$ nd cooling fan speed.

The Regulation UN ECE 51R also defines the measuring conditions in the event if vehicle is equipped with automatic transmission. During measurements, at drive conditions, the bus approaching to the line (AA') at constant speed of $\left(\mathrm{V}=30,40\right.$ and $\left.50 \mathrm{~km} \bullet \mathrm{h}^{1}\right)$. The driver accelerates the bus, from the moment when front end of the bus reaches the reference line, to the moment when back end of the bus passing the line (BB'). We were measured the maximum value of the noise on both sides of the vehicle, whereby, the measurement repeated twice. The highest measured value is rounded to decibel, according to the standard, Tables 4 and 5. At conditions of driving bus, the noise emission of (CNG-1) bus is lowering significantly compared to the limited 
value of $80 \mathrm{~dB}(\mathrm{~A})$. The noise emission of (CNG-1) bus at driving conditions at speed of $\left(V=50 \mathrm{~km}^{\circ} \mathrm{h}^{-1}\right)$ is lower about $6 \mathrm{~dB}(\mathrm{~A})$, compared to the measured emission value of diesel bus at similar conditions. The results marked as $\left(^{*}\right)$ in the Table 5, represent the values obtained by measuring the noise emission of the (CNG-1) bus, when is engine of fan in cooling system in second speed. External noise of (CNG-2) bus in driving was not measured.

\section{Internal noise measuring of buses at stationary conditions}

Measurement method of noise inside the vehicle at stationary conditions was defined in the standard ISO M.NO.401. During measurement, the engine speed is the same as during measurement of the noise emission buses in stationary conditions. Standard defines three measuring points, as follows: the driver's seat, middle part of bus and the last row of seats, close to the engine. The Table 6 below shows the value measurement in all three measurement points. All time, during measurements, instrument with a microphone is positioned in the direction of driving a bus. Measuring in all three points, it is performed twice, and as the result is shown the maximum whole value. The result is approximately same the internal noise of (CNG-1) and diesel buses. The measured internal noise of (CNG-2) bus is quite higher. The primary source of internal noise on the bus is interior with a lot of plastic.

\section{Measurement of noise due to compressed air}

With UN ECE $51 \mathrm{R}$ is stipulated that noise of buses, because of the compression of air in the pneumatic systems, need to be measured as follows: on idle, at a distance of $(7 \mathrm{~m})$ from the vehicle and at a height of $(1.2 \mathrm{~m})$ along the transverse plane in relation to the direction of driving on both sides of vehicle.

Table 4: Noise emission of experimental diesel bus at driving conditions, $d B(A)$

\begin{tabular}{|c|c|c|c|c|}
\hline Bus side & Measurement & $30 \mathrm{~km} \cdot \mathrm{h}^{-1}$ & $40 \mathrm{~km} \cdot \mathrm{h}^{-1}$ & $50 \mathrm{~km} \cdot \mathrm{h}^{-1}$ \\
\hline \multirow{2}{*}{ Left } & 1. & 76.6 & 76.6 & 77.7 \\
\hline & 2. & 76.3 & 77 & 78 \\
\hline \multirow{2}{*}{ Right } & 1. & 74.5 & 73.5 & 77 \\
\hline & 2. & 75.9 & 74.4 & 76.9 \\
\hline & Results... & 77 & 77 & 78 \\
\hline
\end{tabular}

Table 5: Noise emission of experimental (CNG-1) bus at driving conditions, $d B(A)$

\begin{tabular}{|c|c|c|c|c|}
\hline Bus side & Measurement & $30 \mathrm{~km} \cdot \mathrm{h}^{-1}$ & $40 \mathrm{~km} \cdot \mathrm{h}^{-1}$ & $50 \mathrm{~km} \cdot \mathrm{h}^{-1}$ \\
\hline \multirow{2}{*}{ Left } & 1. & $75.8^{*}$ & 71 & 77.1 \\
\hline & 2. & $76.3^{*}$ & 72.4 & 70.3 \\
\hline \multirow{2}{*}{ Right } & 1. & 69.4 & 70.7 & 71.8 \\
\hline & 2. & 71.2 & 71.8 & 70.9 \\
\hline & Results... & 76 & 72 & 72 \\
\hline
\end{tabular}

The results of measurements with appropriate regimes are shown in Table 7.The results represent the noise caused during venting of air pressure regulator, on idle speed. Also measured is the noise due to ventilation, during activation of the working and auxiliary brake; as well as during the activation of additional compressed air system (doors etc.).Before start of each next measurement (after a previous) needed is to waiting when compressor supplement the pressure up to a maximum set value. Measured value does not exceed limit prescribed by the Rules72 $\mathrm{dB}(\mathrm{A})$. During the homologation of buses with a diesel engine, it is measured noise due to air compression of $65 \mathrm{~dB}(\mathrm{~A})$. Noise due to air compression of (CNG-2) bus was not measured.

\section{CONCLUSIONS}

The noise caused with city traffic has a negative impact to a large extent to life quality. In the Republic of Serbia as well as in other parts worldwide, the noise emission which is generated of traffic is becoming a very serious problem, especially in large industrial cities. During exploring, we are confirmed the bus reconstruction in terms of reducing noise emissions. That way, by replacing the existing powertrain diesel buses, and installation of the drive system to natural gas, it can be reduced noise emission of buses. It was registered a significant reduction of the external noise of (CNG-1)bus, compared with the noise emission of the same type diesel bus. 
Table 6: Internal noise of experimental diesel and CNG buses at stationary conditions, $d B(A)$

\begin{tabular}{|c||c||c|c||}
\hline \multirow{2}{*}{ Powertrain } & \multirow{2}{*}{ Measurement } & \multicolumn{2}{c|}{ Engine speed } \\
\cline { 3 - 4 } & & Low idle & $\begin{array}{c}\text { High idle, } \\
18001 \cdot \text { min }^{-1}\end{array}$ \\
\hline \multirow{3}{*}{ Diesel } & 1. & $60 / 64 / 60$ & $60 / 64 / 68$ \\
\cline { 2 - 4 } & 2. & $60 / 64 / 60$ & $60 / 64 / 68$ \\
\cline { 2 - 4 } & Results ... & 64 & 68 \\
\hline \hline \multirow{3}{*}{ CNG-1 } & 1. & $60 / 60 / 63$ & $60 / 62 / 67$ \\
\cline { 2 - 4 } & 2. & $60 / 6064$ & $60 / 63 / 66$ \\
\hline \hline \multirow{3}{*}{ CNG-2 } & Results... & 64 & 67 \\
\cline { 2 - 4 } & 1. & $63 / 72 / 73$ & $64 / 66 / 71$ \\
\cline { 2 - 4 } & 2. & $62 / 70 / 74$ & $64 / 65 / 70$ \\
\hline \hline
\end{tabular}

Reducing noise emission is evidenced also during driving of the bus. Internal noise emission of the bus is not too much lower. The primary source of internal noise on the bus is interior with a lot of plastic. Noise emission of (CNG-2) bus is higher in all regimes. This is bus of the second manufacturer, not fully low floor as (CNG-1), but is with same propulsion system on CNG. Noise emission of (CNG1) bus due air compression inside of the pneumatic system is lower only for $2 \mathrm{~dB}(\mathrm{~A})$,compared to diesel bus at similar conditions. Main reason for this is air compressor with one cylinder and more time during duty cycle. The problem can be solved by installing the compressor with two cylinders, whose operating time under load is lesser, due to bigger capacity. Generally, by applying the CNG buses instead of the existing ones with diesel engine, a considerable decline in noise emission would be achieved. That way it can be reduced the noise emission in transport, thereby contributing to the preservation of human health, too.

Table 7: Noise due to air compression of (CNG-1) bus $d B(A)$

\begin{tabular}{|c||c|c|c||}
\hline \multirow{2}{*}{$\begin{array}{c}\text { Measurement } \\
\text { conditions }\end{array}$} & $\begin{array}{c}\text { Microphone } \\
\text { position and } \\
\text { bus side }\end{array}$ & $\begin{array}{c}\text { Low idle } \\
\text { first mea- } \\
\text { surement }\end{array}$ & $\begin{array}{c}\text { Low idle } \\
\text { second } \\
\text { measure- } \\
\text { ment }\end{array}$ \\
\hline \hline $\begin{array}{c}\text { Ventilation } \\
\text { the pressure } \\
\text { regulator }\end{array}$ & Left & 60.5 & 60.5 \\
\cline { 2 - 4 } & Right & 58 & 57.6 \\
\hline \hline $\begin{array}{c}\text { Activation of } \\
\text { the working } \\
\text { brake }\end{array}$ & Left & 62.7 & 63 \\
\cline { 2 - 4 } & Right & 63.7 & 63 \\
\hline $\begin{array}{c}\text { Activating } \\
\text { the auxiliary } \\
\text { brakes }\end{array}$ & Left & 61.8 & 61.1 \\
\cline { 2 - 4 } & Right & 58 & 59 \\
\hline \hline \multicolumn{2}{|r|}{ Results... } & 63 \\
\hline
\end{tabular}

\section{REFERENCES}

1) Hoffman, K., Benz, M., Weirich, M., Herrmann, H. O., (2014). The new MercedesBenz medium duty commercial natural gas engine. MTZ worldwide, 75, 11, 4-10.

2) Milojevic,S. and Pesic,R., (2012). Theoretical and experimental analysis of a CNG cylinder rack connection to a bus roof. Int. J. of Automotive Technology.13, 3, 497-503.

3) Payri, F., Torregrosa, J. A., Broatch, A., Monelleta, L., (2009). Assessment of diesel combustion noise overall level in transient operation. Int. J. of Automotive Technology.10, 6, 761-769.

4) Živanović, Z., Petković, S., Mišanović, S., Holo, A., Šakota, Ž., (2015). Natural Gas Buses in Serbian Public Transport - Some Operational Experiences. FME Transactions, 43, 2, 89-98.

5) Kojic, M., Slavkovic, R., Zivkovic, M., Grujovic, N., (1998).Finite Element Method I Linear Analysis, (in Serbian), Faculty of Mechanical Engineering, Kragujevac.

6) http://www.euro.who.int/en/health-topics/environment-and-health/noise/data-and-statistics, retrieved on May $15^{\text {th }}, 2016$.

7) http://www.paragraf.rs/propisi/zakon_o_zastiti_od_buke_u_zivotnoj_sredini.html, retrieved on May 15th, 2016.

8) http://www.unece.org/fileadmin/DAM/trans/ main/wp29/wp29regs/updates/R051r3e.pdf, retrieved on May $15^{\text {th }}, 2016$.

Paper sent to revision: 25.05.2016.

Paper ready for publication: 18.08.2016. 